\title{
Eroticism as a Cultural Phenomenon in Archaic and Early Traditional World: Posttraditional View
}

\author{
Philipp Tagirov \\ Department of Social Philosophy \\ Peoples Friendship University of Russia \\ Moscow, Russia \\ E-mail: tagirov_fv@pfur.ru
}

\begin{abstract}
In his article the author presents the analyses of cultural phenomenon of eroticism as it is found in societies of archaic and early traditional type. The study rests on author's distinction between love, sexuality and eros (in a narrow sense) that constitute the integrity of erotic subjectness. Main practices of eroticism are divided into mundane and sacred aspects where the former includes matrimonial and nonmatrimonial traditions and the latter is presented by fertility rituals, sexuality as an instrument of worshiping gods and hierogamy repetition rites.
\end{abstract}

Keywords-archaic culture; eros; eroticism; hierurgy; love; matrimony; patriarchalism; sexuality; traditional society

\section{INTRODUCTION}

Studying intercultural communication, or communication in cross-cultural field, we should keep in mind that the most problematic questions arise when we try to construct certain mental bridges among people who belong not just to different cultures but to different cultural types.

One of the most fundamental cultural distinction lies on the borderline between so called "traditional" and "modern" societies. The task of understanding the frame dispositions of discourse in various fields of life should be primary to our attempt of understanding a person who acts and speaks according to that discourse. The sphere of eroticism, though it is often avoided, suppressed or marginalized in "serious" scientific debates, meanwhile remains a half-hidden but still highly influential subsystem of society.

In a given article the borders of the modern world are assumed to be not so historically as structurally. The concept of the modern society depicts social organization which is post-traditional by its forms and principles. As our conceptual reasons require we address the traditional society as almost an ideal type that is believed to represent as closely as possible its early stages. The propositions of the article can be applied to a contemporary traditional society only with some serious elaborations because of its certain diffusive nature for it inevitably and regularly interacts with societies of modern, post-traditional type [1].

When we mention "eroticism" (in a broad sense) we speak of the complex phenomenon consisted of love, sexuality and strictly eros. Here "love" includes firstly personal sympathy towards the individual uniqueness of the other as well as necessary care for him/her (solicitude about his/her being). "Sexuality" is thought as activity bound (directly or indirectly) to the functioning of genitals and aimed either at human reproduction or at the production of pleasure. "Eros" is taken with a meaning which is close to the one of Plato or Bataille - as a transgressive aspiration of a finite being to the overcoming of its limits [2].

\section{Mundane AND SACRED PRACTICES OF EROTICISM IN ARCHAIC AND EARLY TRADITIONAL SOCIETIES}

As far as we know in archaic and early traditional societies the main practices of the self as a subject of eroticism can be generally divided into two major aspects which are profane (mundane) and sacred (directly connected with some religious rites). "Fig. 1" However, despite the commonly shared opinion it is important to note that for a man of traditional model of thought these two aspects usually aren't in contradiction, do not oppose each other and moreover, as M. Eliade, for instance, pointed out in a number of his works, for this kind of thought the strictly, exclusively profane area and thereby exclusively profane practices do not exist. The contradistinction of the profane and the sacred as well as considering the profane as external to the sacred and the sacred as a sort of "an island", a field distinguished from the mundane are mostly ideas of a man who thinks of himself and problematizes himself (and the other) outside the logic of the sacred. For inside this logic nothing is thought to be completely torn apart or excluded from sacred models because everything that exist and all that happens to a subject is in some sense sacred. Thus speaking of dividing of major practices of eroticism into profane and sacred aspects it's reasonable to keep in mind that though both aren't thought independently from particular structures of the sacred the first aspect (profane) includes certain practices of everyday life which obviously are influenced by some sacred powers and also may have consequences in super-natural reality (such as anger or blessing of gods of harvest, afterlife judgment, karmic retribution, etc.) but in themselves (these practices) do not aimed to direct interaction with sacred principles and do not address particular sacred powers that is, in other words, don't have a dominating ritual purpose. On the contrary the prime purpose of practices of the second aspect is a ritual addressing to the sacred, specific interaction 


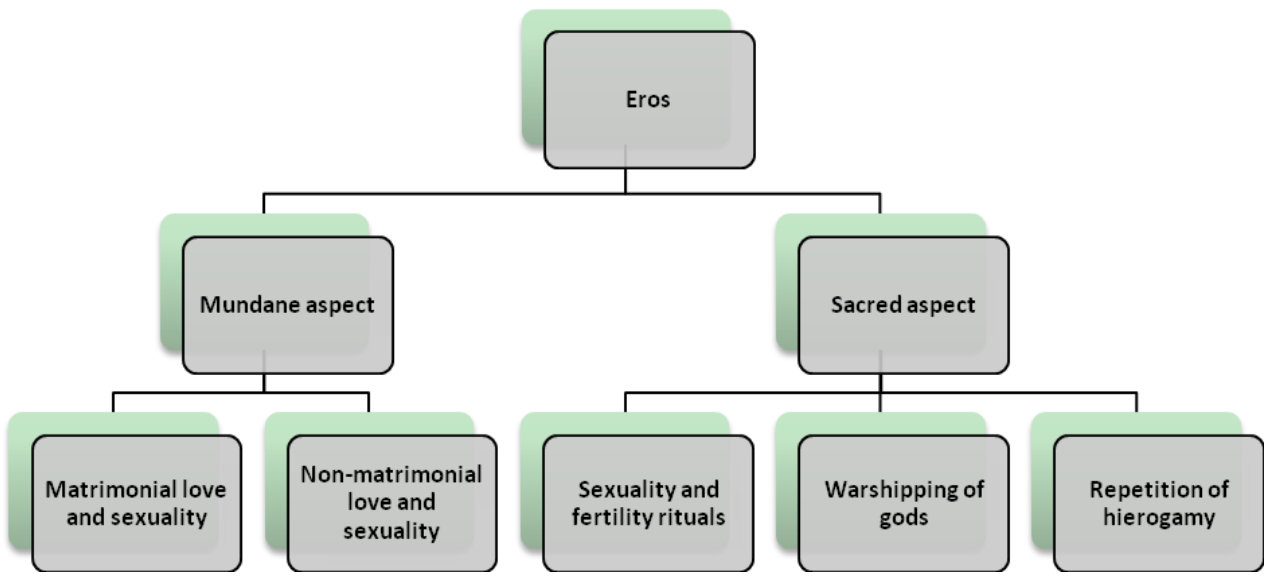

Fig. 1.

After thus marking the division between profane and sacred aspects we should admit that despite rich variety of erotic practices found in traditional cultures we can distinguish basic forms of organizing of eroticism according to each of these contexts. We designate two magister lines problematized within the discourse of the profane aspect of eroticism which are definitely, on one hand, practices carrying the matrimonial signification (which in this article will be paid the special attention because of its central for our study institutionalized position) and, on the other - those manifested beyond it. In the contextual field of ritual practices main institutionalized models will be, firstly, ceremonies and rites built around the presumed connection between human sexuality and cosmic and natural powers of fertility, then, secondly, ritualized forms of eroticism performed as an act of offering to gods and spirits and, finally, shared by many religious and mythological discourses vision of sexual coupling between and woman as a symbolic renewal and reactualization of hierogamy, the marriage of the divine couple that gives birth to all things.

\section{ABOUT THE ORIGIN OF MATRIMONY AS A MUNDANE CENTRE OF EROTICISM PRACTICES}

Studying the matrimonial institute, it's reasonable to analyze it not just as one of the conditions that mark conceptual field of possible practices of the self as a subject of eroticism. We should also take into account that the institution of marriage shows itself among first social institutes (if not the very first); for the traditional society it functions as one of the main systemizing elements because it orders reproductive relations among people as well as a large complex of adjacent practices and a number of issues that are beyond the borders of exact sexual and erotic problematics and primarily belong to political and economic relations.

The contemporary society faces numerous symptoms that signify a crisis of the traditional matrimonial institution. This can mean either the crisis of the whole society seen through the point of view of traditional structures or the manifesting ability of the society to reestablish its subsystems around some other elements than traditional (traditionally patriarchy) family and the restructuration (continued for decades or even centuries) of the main social, economic, political, cultural and symbolic mechanisms that previously were closely connected to the matrimonial institute. If so the call for exact restoration of the traditional matrimonial values that should work for the "health" of the society could have only a partial effect for, though the crisis of traditional matrimony is undoubtedly one of the most important reasons obstructing the historical transference of traditional values (for example, between generations), the crisis itself tends to be not the origin but rather one of the manifestations of some global social transformation.

Historical forming of the matrimonial institutions proceeded in direct connection with the transition from endogamic to exogamic relations that is with the imposing of the restrictions concerning the possible sexual partners among the relatives. Presently there is no simple and univocal explanation of what exactly provided the establishing of the prohibition of the incestuous forms of sexual relations in the first place. In this case it could be relevant to follow, for instance, I. Kon and divide all possible theories about the origin of that prohibition into three groups [3]. The first one consists of theories with biological arguments that centers on the problem of degeneration of the gene pool caused by prolonged endogamic relations that prevent new genetic material from coming. The second group unites psychological theories that point out the necessity of the newness of a sexual object which is required for sexual attraction while close relatives generally do not possess this newness in our eyes. And finally the third group consists of theories that derive the tabooing of incestuous marriage from the need for regulated social relations because no society could exist without a certain stability, predictability, in other words institutionalization of the relations among its members. Though in developed cultures the relations about the forms and objects of sexual partnership are often believed to be secondary because of some shift of the points of problematization from already "settled", "obvious" questions to the new "challenges", they tend to be fundamental for the emerging human society.

The last group seems to be the most interesting for us for it refers to social factors that is historically contingent reality 
that can be formed within various discoursive context. From this point of view, the theory of a gift proposed by Levi Strauss is quite interesting for the studies of gender and sexuality. It notices that the archaic principle of economic exchange (in the contrary to the contemporary one that forms the capitalistic economical order and demands the minimizing of the expenses with the maximizing of the profit) means the exchange of gifts when each of the participants offers the most valuable thing he possesses. In this type of society woman is mostly deprived from her subjectness and understood as an object of possession, and daughters and sisters become the most desirable and most highly evaluated object for their fathers and brothers who offer them to the men of another clan and get their daughters and sisters in return. Finalizing our brief excursus to the possible origin of matrimonial institution we ought to mention the idea of G. Bataille who highly estimating the works of Levi Strauss claims that we should pay our primary attention not to the principle of "gift - return gift" but to the universality of the ban of the sexuality as such that is well known to any human (we add: patriarchic) culture despite the variety of forms that ban manifests itself. According to Bataille when man ceased to be a mere animal and recognized himself as a specific being he at the same time learned the fear of the breakthrough of his own animal nature which is being constantly overcome but never wholly expelled or wholly got under the conscious control [4]. This is the point where the discontinuous human existence comes to the edge of return to the continuity which, on one hand, man desires as a state of existential totality but, on the other hand, terrifies him with the possibility of losing his humanity [5]. Thus for Bataille the matrimonial sexuality is not the right one while the sexuality outside the matrimonial institutions is banned as a transgression: any sexuality seems to be prohibited and the matrimony is just the main field of the legitimated transgression, the trespassing of the universal ban allowed in certain limits.

\section{EROTICISM OUTSIDE THE SACRED RITUAL: TRADITIONAL PATRIARCHALISM}

In most archaic and ancient societies a man achieves his subjectness in the field of eroticism by conforming the structures of the patriarchic type. A number of fundamental values of patriarchic matrimonial relations often seem to be exclusively right and even exclusively possible in the context of our contemporary discoursive practices as well. Despite the historic evidences of matriarchic cultures the current state of our scientific knowledge cannot provide us with absolute certainty whether matriarchalism was the primary form of social relations (if so it could let someone think of it as an original non-patriarchic principle of social organization that doesn't stand down before patriarchalism and probably even surpasses the latter), or did it emerge in parallel to patriarchalism, or did it become some historic deviation from dominating patriarchic line [6. Chapter 1][7][8].

So, how the complex phenomenon of "love-sexualityeroticism" that integrates all practices of eroticism manifests itself in traditional matrimony? It's well known that main functions of a traditional patriarchic family are, first of all, the economic function supposing that such family performs as a productive cell of a society, then the function of preserving and transferring of social status, and finally the reproductive function. Hence we may conclude that from the trinity of "love-sexuality-eroticism" only sexuality in its reproductive aspect is necessarily required by the traditional matrimonial institution. In accordance with The Code of Hammurabi in case of the infertility of a woman she ought to bring her husband another woman; that's just one of the most prominent examples that illustrate the priority of procreation for the traditional family [6, Chapter 4]. As for another, nonreproductive, aspect of sexuality that evolves around the pleasure principle we can state that according to the patriarchic logic the role of the subject of pleasure is generally prescribed to man. As many contemporary researchers claim, double standard in relations between men and women is thoroughly spread within the traditional structures including the field of the intimate where a woman herself predominantly thinks of herself as an object of sexual pleasure but not as its possible subject. Meanwhile a man who conceptually associates matrimony in the first place with reproductive sexuality seeks his own non-reproductive sexual self-fulfillment beyond the matrimonial relations and, besides slaves and servants, he usually also finds the institute of prostitution and (in a number of cultures) free women who don't tie themselves with the bounds of marriage and dedicate themselves (like Greek hetaeras or Japanese geishas) to arts or sciences and the art of love among them.

Concerning the love in the sense of individual care for the other in his or her uniqueness and the place of such love in this kind of matrimony we could refer to the formula "marry first and love will follow". If love accompanies the creation of a new family it's obviously thought to be good however its absence, as a rule, cannot be the sufficient reason preventing from marriage determined by a set of causes and personal feelings or choices hardly play the governing role among them. The ancient Greek concept of "storge", familiar love grown up from a long-term everyday commonality of mutual solicitudes and successes, can be a classic example of love in traditional matrimonial institution.

If we ask about the eros with its essential transgressive aspiration then we might admit that though (if we follow Bataille's idea) it inevitably exists in matrimonial sexuality for any sexuality is prohibited as such (as it was already mentioned) the non-matrimonial sexuality, sexuality beyond the boundaries of marriage appears to be a kind of doubly transgressive because it adds the trespassing of certain social norms to the general sexual transgression.

\section{Man as a SubJect of ERoticism in Practices of HIERURGY: FROM MAGIC TO COSMOGONY}

As for the "sacred" aspect of ancient and archaic practices of eroticism we need to mention first that, while in "profane" everyday "domestic" field models of matrimonial and non-matrimonial are not just divided but also opposed (though one doesn't exclude the other, at least for man), models of the sacral purpose even if derive compose a complex constellation which integrity is provided by the 
integrity of the sacred realm as it is revealed in the context of religious and mythological discourse.

The most widely spread element of this discourse (from the perspective of this article's problematics) is a conceptualization of the relations between human sexuality and cosmic powers of fertility [9. Chapter 11.] [6. Chapter 4, $\S \S 6-8$.$] [10]. These relations are believed to be bilateral. On$ one hand, we learn of numerous rites where the manifestations of sexuality (including the most excessive ones) serve the awakening of the natural fertile energies whether they result in the productivity of the crops or in the breed of the cattle. On the other hand, ancient cultures for ages practice multiple rituals of various content aimed to help a man himself (or a woman herself) obtain reproductive fertility by addressing the sacred powers (different forms of sexual magic, incubations in the sacred places and so on). This context justifies, for example, the special status of the pregnancy and a pregnant woman who is sanctified in many archaic and ancient cultures though ambivalently (as it often happens in cases of the sacred): she is believed to have the abilities of blessing, healing, sharing her fertility with the land, with cattle, with other people but her presence without properly performed rites (protective ones as well as other) can result in curses, spoilage or bad harvest. The prime reason should be sought in the cosmogonic situation of the coming childbirth: the birth of a man is a beginning of the new, emerging of something that previously didn't exist and in this sense is similar to cosmogony, to the beginning of a new world.

Practices that include eroticism as a form of god worshipping are also wide-spread [9. Chapter 12.]. The visiting of a temple where sacred prostitution was practiced is a case of this ritual sacrifice. Also the daily experience of matrimonial closeness often obtains a new dimension by comparing the act of intimacy with a sacrifice (the sacrifice of Soma, for instance) or by comparing a woman with the sacrificial altar. However, it would be a mistake if we limit this sort of conceptualization only to ancient polytheistic cultures. The prayer that dedicate the coitus between a husband and his wife to the higher mission accompanies certain matrimonial ritual practices in monotheistic religions.

Besides that, we should also mention the ritual repetition of hierogamy that is divine union between some primordial couple of gods often presenting the sky and the earth like Nut and Geb in the Egyptian tradition or Uranus and Gaea in the Greek one. Even those cultures where the concept of hierogamy doesn't have a definite manifestation can preserve it in some latent or occult forms. Kabbalah, for instance, as J. Evola claims, understands every genuine marriage as a symbolic reactualization of the sacred union of God and Shekinah, his feminine aspect [11].

If now we apply our model of triple conceptual integrity of eroticism to these practices of hierurgy we definitely find that personal line of love gives way to the impersonal, superpersonal and archetypical. Sexuality retains its productivity but the latter is no more dedicated to the production of pleasure and even the procreation in a sense of merely reproduction. In the ritual dimension sexuality became creative, cosmogonic. As for eros in the narrow sense, for the first time it obtains what it fundamentally lacks when it's limited to the solely social and psychological levels, that is the ability of complete fulfilling of its transgressive aspiration which means not just stepping towards the limits of one's being but also the possible retrieving of the limitless being. Eros lead us through transgression to the transcendent.

\section{CONCLUSION}

Studying the cultural phenomenon of eroticism in archaic and early traditional societies we divide it into three main elements that are love, sexuality and eros (in the narrow sense). These elements find diverse manifestations in mundane and hierurgy fields. The mundane practices are generally formed around patriarchal matrimony resulting into focusing on the reproductive aspect of sexuality and the dependent status of love. The transgressive eros is mostly manifested in non-matrimonial relations while in certain way the matrimony itself can be understood as a legitimized transgression of the banned sexuality.

In all practices of hierurgy the subjectness of man in eroticism is obtained along with the loss, refusal or overcoming of personal subjectness of a human being. Sacred practices are as effective as more a man assimilates with the sacred, and he assimilates with the sacred (believed to be of a cosmic nature or even transcendent to the cosmic realm) by ceasing to be merely human and becoming a vessel and a conductor of what fundamentally exceeds any personal and subjective human order.

\section{REFERENCES}

[1] Giddens, Antony. Runaway World: How Globalisation Is Reshaping Our Lives. - Taylor \& Francis, 2003. Chapter 3.

[2] Tagirov, Philipp V. Eros, Love and Sexuality: Defining the Problematic Field. // Rediscovering the contemporarity. - Peoples' Friendship University of Russia, Publishing House, Moscow, 2011.

[3] Kon, Igor. Sexuality and Culture. - SPbGUP, Saint Petersburg, 2004. Lecture 1.

[4] Bataille, Georges. Eroticism, trans. by Mary Dalwood. - Penguin, London, 2001. Part 2.

[5] Bataille, Georges. The History of Eroticism in The Accursed Share Volumes II \& III, trans. by Robert Hurley. - Zone Books, New York, 1991. Introduction and Part 1.

[6] Vardiman, Ernst E. Die Frau in der Antike. Sittengeschichte der Frau im Altertum. - Econ, München, 1982. Part 1, Chapter 1.

[7] Eliade, Mircea. Myths, Dreams and Mysteries. - Harper \& Row, 1975. Chapter 3.

[8] Russell, Bertrand. Marriage and Morals. - Liveright, New York, 1970. Chapters 2-3.

[9] Frazer, Sir James George. The Golden Bough. - The Macmillan company, New York, 1925

[10] Eliade, Mircea. The Sacred and The Profane. The Nature of Religion, trans. by Willard R. Trask. - A Harvest Book, Harcourt, Brace \& World, Inc., New York, 1963. Chapter 3, §10.

[11] Tokarev, Sergey A. Early Forms of Religion. - Politizdat, Moscow, 1990. Chapter 4, §§2-3.

[12] Evola, Julius. The Metaphysics of Sex. - Inner Traditions, New York, 1983. Chapter 6, §3. 